\title{
Article \\ Septic System Impacts on Source Water: Two Novel Field Tracer Experiments in Fractured Sedimentary Bedrock
}

\author{
Rachael Marshall *, Jana Levison *, Beth Parker and Edward McBean
}

check for updates

Citation: Marshall, R.; Levison, J.; Parker, B.; McBean, E. Septic System Impacts on Source Water: Two Novel Field Tracer Experiments in Fractured Sedimentary Bedrock. Sustainability 2022, 14, 1959. https:// doi.org/10.3390/su14041959

Academic Editor: Franco Salerno

Received: 25 October 2021

Accepted: 3 February 2022

Published: 9 February 2022

Publisher's Note: MDPI stays neutral with regard to jurisdictional claims in published maps and institutional affiliations.

Copyright: (C) 2022 by the authors. Licensee MDPI, Basel, Switzerland. This article is an open access article distributed under the terms and conditions of the Creative Commons Attribution (CC BY) license (https:// creativecommons.org/licenses/by/ $4.0 /)$.
School of Engineering, Morwick G360 Groundwater Research Institute, University of Guelph, Guelph, ON N1G 2W1, Canada; bparker@uoguelph.ca (B.P.); emcbean@uoguelph.ca (E.M.)

* Correspondence: rachael.marshall@sharedvaluesolutions.com (R.M.); jlevison@uoguelph.ca (J.L.)

\begin{abstract}
Septic systems are a common contributor of contaminants to groundwater that have implications for source water protection, particularly in fractured sedimentary bedrock environments. Two 24-h tracer experiments were performed that applied (1) the dye Lissamine Flavine FF and (2) three artificial sweeteners (acesulfame, sucralose, and cyclamate) in the leaching bed to examine solute transport from a single-family septic bed to a multilevel monitoring well installed in fractured sedimentary bedrock on a First Nation reserve in Southern Ontario, Canada. Tracer was first observed $3 \mathrm{~h}$ and $20 \mathrm{~min}$ after deployment, and breakthrough curves showed that multiple pathways likely exist between the septic bed and the monitoring well. Cyclamate concentrations were more elevated than expected compared to other studies that examined cyclamate's attenuation in the laboratory and in porous media aquifers. Solute transport through the septic bed was analyzed with the numerical modeling software Hydrus 1D, which indicated that the septic bed may be too thin, located directly on bedrock, underlain by fractured soils, or bypassed through a short-circuit. The rapid transport of septic leachate to fractured sedimentary aquifers is problematic for First Nation and rural communities. More stringent regulations are needed for the design and use of septic systems in these environments.
\end{abstract}

Keywords: source water protection; groundwater quality; rural water sources; fractured sedimentary rock; tracer time of travel experiments; septic system leach bed; artificial sweeteners

\section{Introduction}

Source water protection is a complex process that must consider a number of sociopolitical and technical factors, including jurisdictional considerations, flow and transport of water and contaminants in the natural environment, and built infrastructure [1]. While many advances have been made towards protecting drinking water sources around the world in recent years [2-7], issues persist in many environments, including vulnerable hydrogeology, aging or inappropriate infrastructure, and where socio-economic and other factors have made it difficult to implement adequate source water protection measures, as is the case in many rural and Indigenous communities $[3,5,6]$.

It is well-known that septic systems are a common contributor of contamination to groundwater, streams, and lakes [8-16]. Particularly in fractured rock environments, septic systems can pose a threat to groundwater and nearby surface water bodies due to the rapid transport of contaminants along fractures with little attenuation. In sedimentary fractured rock, the behaviour of dissolved phase solutes is influenced by the porous nature of the matrix blocks between fractures. It has been well-established that strong matrix diffusion effects cause contaminant mass to be transferred from fractures to the porous matrix where it is stored and slowly released, delaying arrival and reducing peak concentrations, but impacting groundwater sources for many decades [17-21]. Despite the risks septic systems pose to the environment, septic systems are widely used in rural areas across Canada and the United States. They are often approved for use in vulnerable fractured rock aquifer 
settings if the overlying overburden meets grainsize and minimum thickness requirements; although, increasingly, evidence shows that groundwater quality impacts from septic systems are common [14].

In Canada, septic systems are a common form of wastewater treatment and disposal in Indigenous communities, which are predominantly rural. In a 2011 national assessment of First Nations' water and wastewater systems, 36\% of homes on reserves were found to use septic systems [22]. However, the use of septic systems can be problematic on reserves; of the individual systems examined in the national assessment, $47 \%$ had operational issues and approximately $20 \%$ were discharging wastewater directly to the ground surface [22]. Some of these issues were related to the improper installation of septic beds in unsuitable soils, while others were related to a lack of maintenance and/or the age of the septic systems [22]. Given the limited funds available to First Nation bands for wastewater infrastructure [23], timely maintenance and replacement of septic systems is often difficult to achieve due to financial barriers. In terms of improper septic system installations, a lack of regulation and training for contractors at the time of installation may be a contributing factor (e.g., prior to 1997, contractors were not required to be licensed or trained to complete septic system installations in Ontario [24]). Regardless of the causes of these malfunctions, failing septic systems pose serious health risks for Indigenous communities in Canada, and are particularly troubling for Indigenous communities located above fractured bedrock aquifers, where septic system malfunctions can lead to the rapid and widespread migration of contaminants in groundwater without much attenuation [14]. Even when no malfunctions are visible, septic systems pose a threat in these vulnerable aquifer settings where groundwater flow rates are rapid [25,26].

Tracer experiments can be used to provide valuable information about the impact of septic systems on the environment. Studies have examined the fate and transport of passive tracers, wherein they simply rely on wastewater constituents present in the flow system such as viruses and bacteria [27-29]; nutrients [30-32]; pharmaceuticals and personal care products [33-35]; and artificial sweeteners [15,16]. Other studies have carried out experiments where tracers, such as fluorescing dyes, have been intentionally added to septic leachate to examine its movement in the environment [13,14,36,37].

Septic system tracer studies are essentially infiltration tracer experiments. Most infiltration studies performed in fractured rock settings have examined shallow and deeper unsaturated zone transport phenomena [38-43]. Few studies conducted in fractured rock settings have examined solute transport from surface to substantial depth in the saturated zone [44,45]. In fractured sedimentary rock environments, while studies have examined passive tracers of wastewater from septic systems to depth [46-48], to the best of the authors' knowledge, only two active tracer experiments have been carried out to examine the transport of solutes from near-surface to substantial depth in fractured sedimentary rock, including an experiment carried out by Harden et al. [49] and an experiment documented by both Alexander et al. [13] and Borchardt et al. [14]. Further, we are unaware of any studies that have used artificial sweeteners as intentionally added tracers of solute transport in groundwater (applied to the ground surface or injected), with known timing and concentration of the total volume. Given that sedimentary fractured rock aquifers can be highly vulnerable to contamination from the near-surface, infiltration tracer experiments have significant potential as a useful tool to assess solute transport from near-surface to depth in this type of setting.

The purpose of this study was to examine the impact to groundwater of an aging single-family septic bed of typical design located above a fractured sedimentary bedrock aquifer on a First Nations reserve in Southern Ontario, Canada using two infiltration tracer experiments. The objectives were to investigate: (1) the effectiveness of overburden protection; and (2) the variation in solute concentration with depth over time. Lissamine Flavine FF, an organic dye, and three artificial sweeteners (acesulfame, sucralose, and cyclamate) were used as complementary tracers due to their range of properties, possible attenuation, and ease of measurement. 


\section{Materials and Methods}

\subsection{Study Area}

This study was carried out in partnership with the Chippewas of Nawash Unceded First Nation. The research site was located on the $64-\mathrm{km}^{2}$ Neyaashiinigmiing First Nation Reserve No. 27, on the eastern shore of the Bruce Peninsula near Wiarton, ON, Canada (Figure 1). The reserve consists of 268 homes, and wastewater treatment is carried out using a combination of septic systems and a lagoon [50].

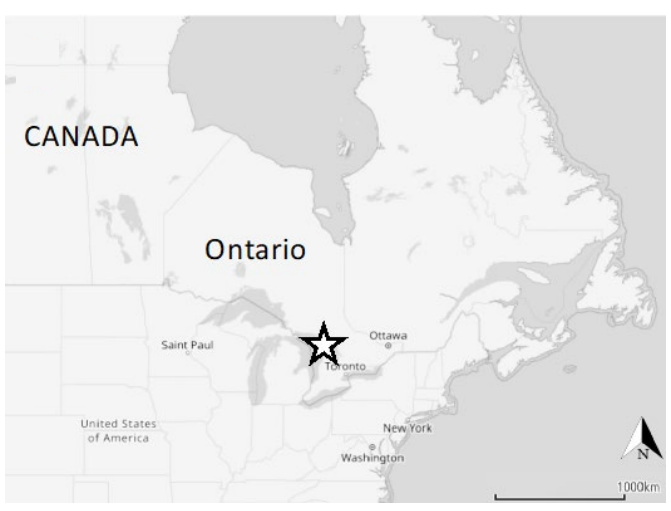

(a)

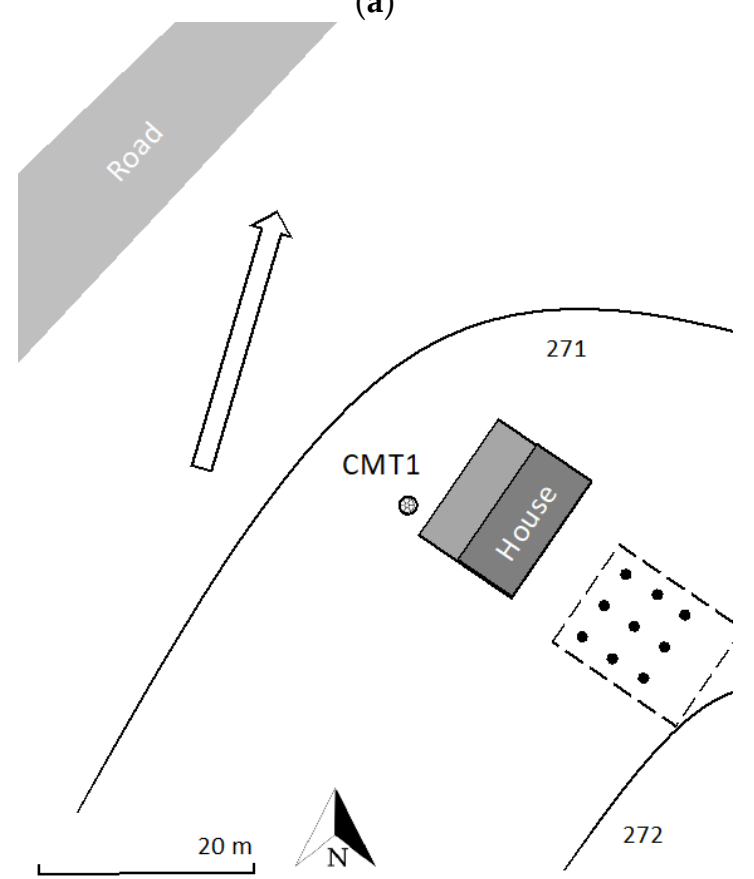

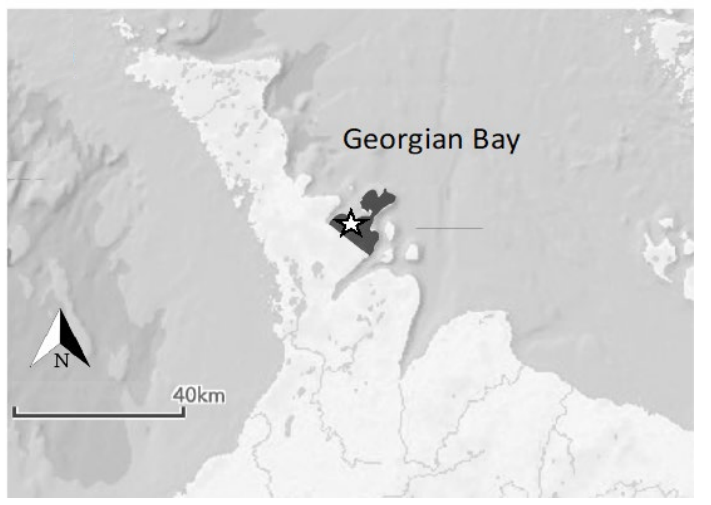

(b)

(c)

Figure 1. (a,b) Location of a 2016 groundwater study conducted on a First Nation reserve in Southern Ontario, Canada (OpenStreetMap contributors, CC-BY-SA, 2018; CHS, Esri, Deforme, NaturalVue, NOAA OCS, 2018). (c) A schematic of the study field site, including the locations of a 7-channel Continuous Multi-channel Tubing ${ }^{\circledR}$ (CMT) multilevel monitoring system and infiltration piezometers installed above an active septic system.

\subsection{Site Characterization}

Neyaashiinigmiing First Nation Reserve No. 27 sits above a fractured Silurian dolostone aquifer overlain by thin to non-existent Quaternary soils ranging from 0 to $2.9 \mathrm{~m}$ [50] with textures ranging from well-drained clay and loam on the northern plateaus of the reserve to poorly drained clay and imperfectly drained clay loam on lower slopes and in depressional areas. Well-drained sands and gravels are present in some areas, such 
as McGregor Harbour and the central village of the reserve [50]. The fractured Silurian dolostone aquifer is underlain by the confining shales of the Clinton group [51]. Many formations are visible in outcrops in the area of the reserve, such as the red shales of the Queenston Formation, the fossiliferous dolostone of the Fossil Hill Formation sharply overlying the interbedded grey-green shales and dolostones of the Wingfield Formation, and the large dolostone ridges of the Gasport Formation [51,52].

Water levels in an unused drinking water well at the site and in two other wells within $350 \mathrm{~m}$ of the site ranged from 14.15 to $16.17 \mathrm{mbgs}$ when downhole geophysical data was collected in September 2014. A seven-channel 403 Continuous Multi-channel Tubing ${ }^{\circledR}$ (CMT) multilevel monitoring well was retrofitted into the unused drinking water well at the site, which is located approximately $15 \mathrm{~m}$ from the septic bed. Downhole geophysical data; hydraulic data (pumping and slug tests); isotopes (tritium, $\delta^{15} \mathrm{~N}$ and $\delta^{18} \mathrm{O}$ ); and monthly groundwater quality data, including anions, Escherichia coli, total coliforms, and artificial sweeteners, were collected from the seven CMT ports from December 2015 to November 2016. Water levels in the CMT ranged from 9.59 to 17.02 mbgs over the course of the sampling period. Depth to bedrock near the multilevel was determined to be greater than $2 \mathrm{~m}$; however, overburden depths are quite variable on the reserve. The formation transmissivity from the unused water well at the site was calculated using the Moench solution [53] to be $1.5 \times 10^{-5} \mathrm{~m}^{2} / \mathrm{s}$ from the pumping test on the open well prior to CMT installation. Interpretation of downhole acoustic televiewer and temperature data resulted in the identification of eight open fractures that likely contribute groundwater to the borehole. Transmissivities from slug tests (carried out following the methodology outlined by Alexander et al. [13]) on CMT ports 2 to 5 , which are $0.58,0.71,0.64$, and $0.89 \mathrm{~m}$ long for ports 1-7, respectively, were calculated using the Barker-Black solution [54] and ranged from $8.1 \times 10^{-8} \mathrm{~m}^{2} / \mathrm{s}$ to $8.4 \times 10^{-7}$ (corresponding to mean hydraulic apertures for each interval from 46 to $101 \mu \mathrm{m}$ ).

Equivalent apertures were calculated using the cubic law:

$$
T=\frac{\rho g}{12 \mu}\left(2 b^{3}\right),
$$

where $T$ is the transmissivity, $\rho$ is the denity of water, $\mu$ is the viscosity of water, $g$ is the acceleration due to gravity, and $2 b$ is the equivalent fracture aperture [55].

Nine shallow piezometers ranging from 0.6 to $1.0 \mathrm{~m}$ in depth were installed over the septic bed in a grid in order to bypass the topsoil layers and allow for direct tracer application to the septic bed (Figure 1). This method was used to simulate transport of solutes from the septic bed to the bedrock aquifer. Soil samples were collected from each piezometer hole and analyzed for grainsize via sieve and hydrometer tests, soil moisture content, and organic carbon content. Soil types included A horizon $(0-20 \mathrm{~cm})$, and gravelly clayey silt $(20-100 \mathrm{~cm})$. Soil moisture content was determined using the gravimetric method [56] and ranged from 12.8 to $19.9 \%$. Organic carbon content was determined using the loss on ignition method [57], and average fraction organic carbon $\left(\mathrm{f}_{\mathrm{oc}}\right)$ values for the A horizon and the gravelly clayey silt were 4.2 and $2.2 \%$, respectively.

\subsection{Infiltration Tracer Experiments}

Two separate 24-h infiltration experiments were conducted in November 2016 and September 2017, the first using the artificial sweeteners acesulfame, sucralose, and cyclamate, and the second using the organic dye Lissamine Flavine FF. Lissamine is a very effective yellow organic dye that has been used as a groundwater tracer since 1976 [58]. It is non-toxic [59], stable, can be detected at high sensitivities, and has a low adsorption tendency [60-62]. Smettem and Trudgill [61] identified Lissamine as the most appropriate water tracer for use in the field under conditions of high flow velocities. It has thus been used successfully as a tracer in fractured rock settings [45,63,64].

Artificial sweeteners have only recently been identified as promising passive tracers of wastewater transport in the subsurface due to their persistence in soils and 
groundwater $[15,16,65-74]$. Acesulfame and sucralose, in particular, have been identified as quite stable in soils infiltrated with untreated wastewater $[66,69,75]$. In a laboratory experiment conducted by Buerge et al. [69] in six soil types under aerated conditions, sucralose, acesulfame, and cyclamate were found to have half-life ranges of 8-124 days, 3-49 days, and 0.4-6 days, respectively, and mean, moisture-corrected half-lives of 9.0, 6.1, and 0.8 days, respectively. Studies conducted in the field have demonstrated that of the three artificial sweeteners, acesulfame has been the most conservative tracer of wastewater impacts to groundwater $[65-67,70]$. Cyclamate, though less conservative, was included as a tracer in this study because analyzing for multiple artificial sweeteners can provide insights about contaminant transport [67].

The infiltration experiments were carried out by purging CMT1 multilevel ports, applying the tracer in the nine piezometers (Figures 1 and 2), and flushing the tracer into the groundwater system with water during approximately the first two and a half hours of the experiments. Samples were then collected from the six multilevel ports (Port 1 was dry) with a Geopump ${ }^{\mathrm{TM}}$ peristaltic pump from Geotech Environmental Equipment Inc. (Denver, CO, USA) paired with Nycoil ${ }^{\circledR}$ LLDPE 1/4-inch OD tubing.

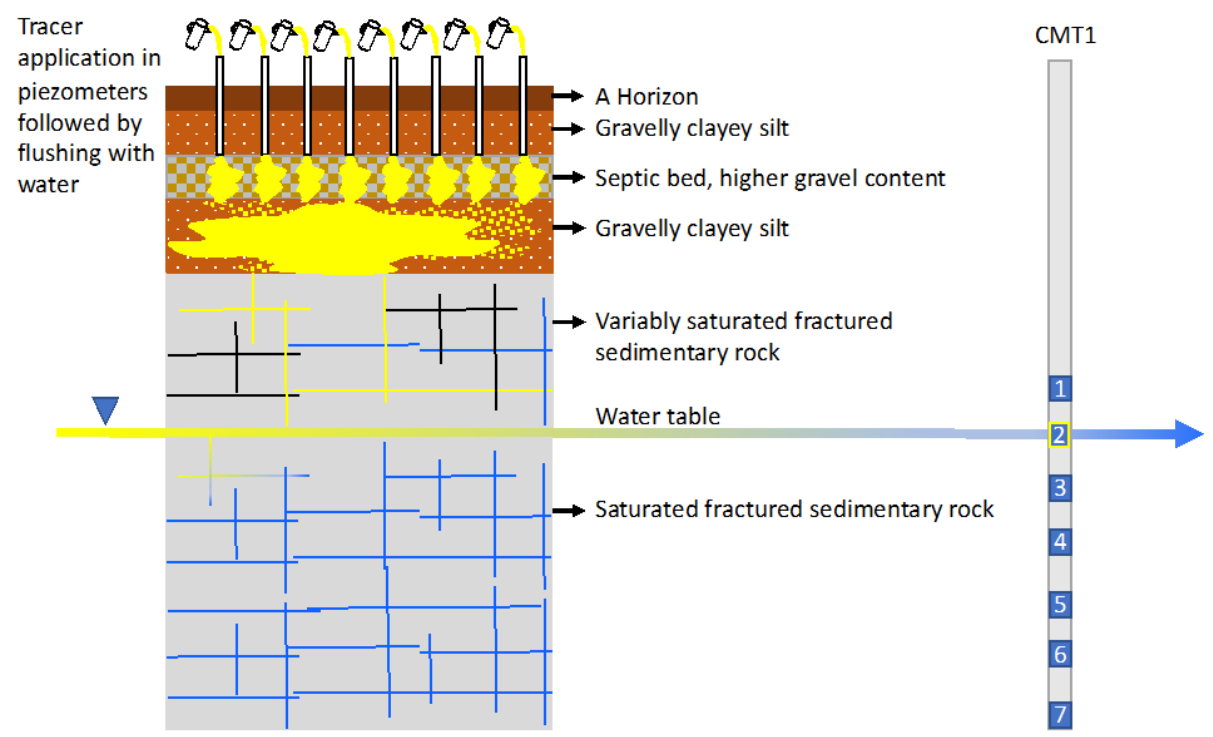

(a)

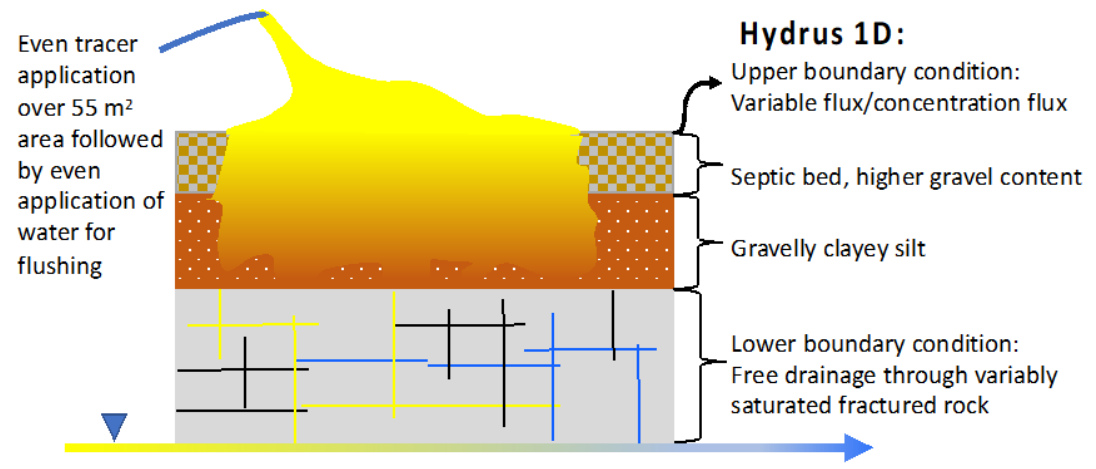

(b)

Figure 2. (a) Conceptual model of tracer transport through the subsurface (the depicted fractures are a conceptualization and are not to scale), and (b) a simplified conceptual model used to model transport from septic bed to bedrock using the software Hydrus 1D [76].

\subsubsection{Lissamine Tracer Experiment}

Approximately $300 \mathrm{~L}$ of $1600 \mathrm{mg} / \mathrm{L}$ Lissamine Flavine FF tracer, purchased from Pylam Products Company (Tempe, AZ, USA), was poured into the nine piezometers at a 
rate of approximately $0.75 \mathrm{~L}$ per minute for $45 \mathrm{~min}$. After tracer application, $600 \mathrm{~L}$ of water (collected from Georgian Bay near the research site) was poured into the nine piezometers and allowed to infiltrate by gravity over a period of $1 \mathrm{~h}$ and $50 \mathrm{~min}$ to 'chase' the tracer into the groundwater system. For each sample collected from the seven CMT ports, turbidity and fluorescence were measured directly in the field. Turbidity was measured using a Hach Model 2100P Portable Turbidimeter manufactured by Hach (Loveland, CO, USA) and fluorescence was measured using a Turner Designs Cyclops-7 submersible fluorometer and DataBank Station manufactured by Turner Designs Inc. (San Jose, CA, USA). Prior to tracer application, background fluorescence values were measured for each of the seven CMT ports. Turbidity values and background fluorescence were removed from each data point.

\subsubsection{Artificial Sweetener Tracer Experiment}

An artificial sweetener tracer experiment was initiated on 20 November 2016 but was unable to be completed due to equipment difficulties. A second artificial sweetener tracer experiment was then successfully conducted on 27 November 2016. Samples were collected from each CMT port to measure background levels of artificial sweeteners prior to the start of the second experiment. No samples could be collected during the first experiment. In both experiments, an artificial sweetener tracer mixture with concentrations of approximately $130 \mathrm{mg} / \mathrm{L}$ of acesulfame, $140 \mathrm{mg} / \mathrm{L}$ of sucralose, and $6400 \mathrm{mg} / \mathrm{L}$ of cyclamate was created by preparing a mixture of Coke Zero ${ }^{\mathrm{TM}}$ (Coca Cola Canada; Toronto, ON, Canada), Splenda ${ }^{\circledR}$ (Tate \& Lyle; London, UK) granulated sweetener, and Sugar Twin ${ }^{\circledR}$ (B\&G Foods, Inc; Parsippany, NJ, US) calorie-free sweetener. A higher dose of cyclamate was added because it is more susceptible to degradation and digestion by bacteria [69]. The tracer was poured into the nine piezometers at a rate of $0.75 \mathrm{~L} /$ minute for $45 \mathrm{~min}$, and then flushed into the groundwater system by pumping of $600 \mathrm{~L}$ of water into the piezometers over a period of $1 \mathrm{~h}$ and $50 \mathrm{~min}$. Samples were collected in HDPE bottles from each CMT port over the course of 24-h. All samples were transported in coolers with ice packs and frozen immediately upon return to the laboratory. Artificial sweetener solid phase extractions were carried out at the University of Guelph and analyzed at Trent University using liquid chromatography and tandem mass spectrometry (LC-MS/MS). The limits of detection for acesulfame, sucralose, and cyclamate were 2, 0.3, and $1.5 \mathrm{ng} / \mathrm{L}$, respectively, and the limits of quantitation were 6,1 , and $5 \mathrm{ng} / \mathrm{L}$, respectively.

\subsubsection{Numerical and Analytical Modeling}

Hydrus 1D Version 4.16, a numerical model that simulates one-dimensional transport of water, contaminants, and heat in variably saturated media [76] was used to simulate tracer transport through the septic bed and the overburden below it. Several conceptual models were tested; most included two soil layers representing: (1) the septic bed as a uniform layer with a higher gravel content; and (2) the soil beneath it, which was assumed to have the same composition as the soil type directly above the septic bed (a gravelly clayey silt) (Figure 2).

The van Genuchten-Mualem single porosity model [77] with no hysteresis was used with variable flux as the upper boundary condition and free drainage as the lower boundary condition. Discretization was retained even along the length of the model, with 101 nodes used to discretize the $1.5 \mathrm{~m}$ soil profile. Since Hydrus 1D is a one-dimensional numerical model, the tracer application was represented as a uniform flux applied evenly to a $55 \mathrm{~m}^{2}$ area on the leachate bed for $0.83 \mathrm{~h}$, followed by a uniform flux of water across the same area for $1.67 \mathrm{~h}$. To simulate the flow coming in from the active septic system, a constant flux of $1000 \mathrm{~L}$ of water (corresponding to $250 \mathrm{~L} / \mathrm{d}$ per person for a four-person household) was applied to the septic bed throughout the run period. The constant flow from the septic system was allowed to reach steady state prior to the application of the tracer in the model.

Unsaturated soil hydraulic properties, including saturated hydraulic conductivity; residual and saturated soil water content; soil water retention parameters; and a tortuosity parameter, were determined by inputting the composition of each soil layer (\% sand, silt, 
and clay) into the Rosetta Lite Neural Network prediction model [78]. The composition of Layer 1 (the septic bed) was simulated as a sandy gravel, and the composition of Layer 2 (the soil beneath the septic bed) was assumed to correspond to the composition of soil samples collected from above the septic bed during piezometer installation (i.e., $34 \%$ gravel, $41.5 \%$ silt, and $24.5 \%$ clay). Due to the fact that no records could be found of the construction details of the septic bed, the thickness of Layers 1 and 2 were assumed to be 60 and $90 \mathrm{~cm}$, respectively, in accordance with the Ontario septic system design specifications [79].

The estimated $\mathrm{K}_{\mathrm{oc}}$ value for Lissamine Flavine FF is 245.5 [45], resulting in an average $K_{d}$ value of 4.3 for the collected soil samples. Given that no soil samples were collected from the septic bed and $f_{o c}$ values could not be determined for this layer, the $K_{d}$ was initially assumed to be 4.3 for both layers.

Outputs from Hydrus 1D were used as inputs in CRAFLUSH to examine solute transport in the fractured bedrock. CRAFLUSH is a one-dimensional, discrete fracture network model that analytically solves the solutions from Sudicky and Frind [80] and Tang et al. [81] to model transport in a set of parallel, evenly spaced, constant aperture fractures while taking into account advection, dispersion, adsorption, and matrix diffusion (see [80] for a fulsome description of the analytical solutions solved by CRAFLUSH). The conceptual model used to inform the CRAFLUSH model was based on an analysis of geophysical logs of the borehole, including temperature and ATV logs that identified eight active fractures in the CMT ports (Figure 3). Solute transport was therefore modeled in eight discrete fractures with an even spacing of $1.62 \mathrm{~m}$. Fracture length from the septic bed to the CMT was assumed to be $34.85 \mathrm{~m}$, which is the shortest possible length assuming all fractures in the dolostone aquifer are either vertical or horizontal (i.e., $15 \mathrm{~m}$ horizontally and $19.85 \mathrm{~m}$ vertically).

Parameters considered for the CRAFLUSH model are included in Table 1. The local hydraulic gradient was calculated from hydraulic head data from four ports with similar depths in CMT1 and CMT2 (a nearby monitoring well [82]) over a period of 14 months.

Table 1. Fractured bedrock parameters.

\begin{tabular}{|c|c|c|}
\hline Parameter & Value & Reference \\
\hline $\mathrm{K}_{\mathrm{f}}$, distribution coefficient, fracture & 0 & Assumption: no organic carbon in fractures \\
\hline$\theta_{\mathrm{m}}$, matrix porosity & $5 \%$ & [83] \\
\hline$\theta_{\mathrm{f}}$, fracture porosity & 1 & Assumption: $100 \%$ porosity in fractures \\
\hline $\mathrm{D}^{*}$, molecular diffusion coefficient in water & $1.62 \times 10^{-6}$ & [64] \\
\hline$\varrho_{\mathrm{b}}$, bulk density of matrix $\left(\mathrm{kg} / \mathrm{m}^{3}\right)$ & 2400 & [84] \\
\hline $\mathrm{K}_{\mathrm{m}}$, distribution coefficient, matrix & 0 & Assumption: no organic carbon in matrix \\
\hline i, hydraulic gradient & $\begin{array}{c}\text { 0.002-0.12 } \\
\text { Average: } 0.03\end{array}$ & $\begin{array}{l}\text { Calculated from head in } 4 \text { ports of CMT1 and } \\
\qquad 2 \text { over } 14 \text { months }\end{array}$ \\
\hline
\end{tabular}




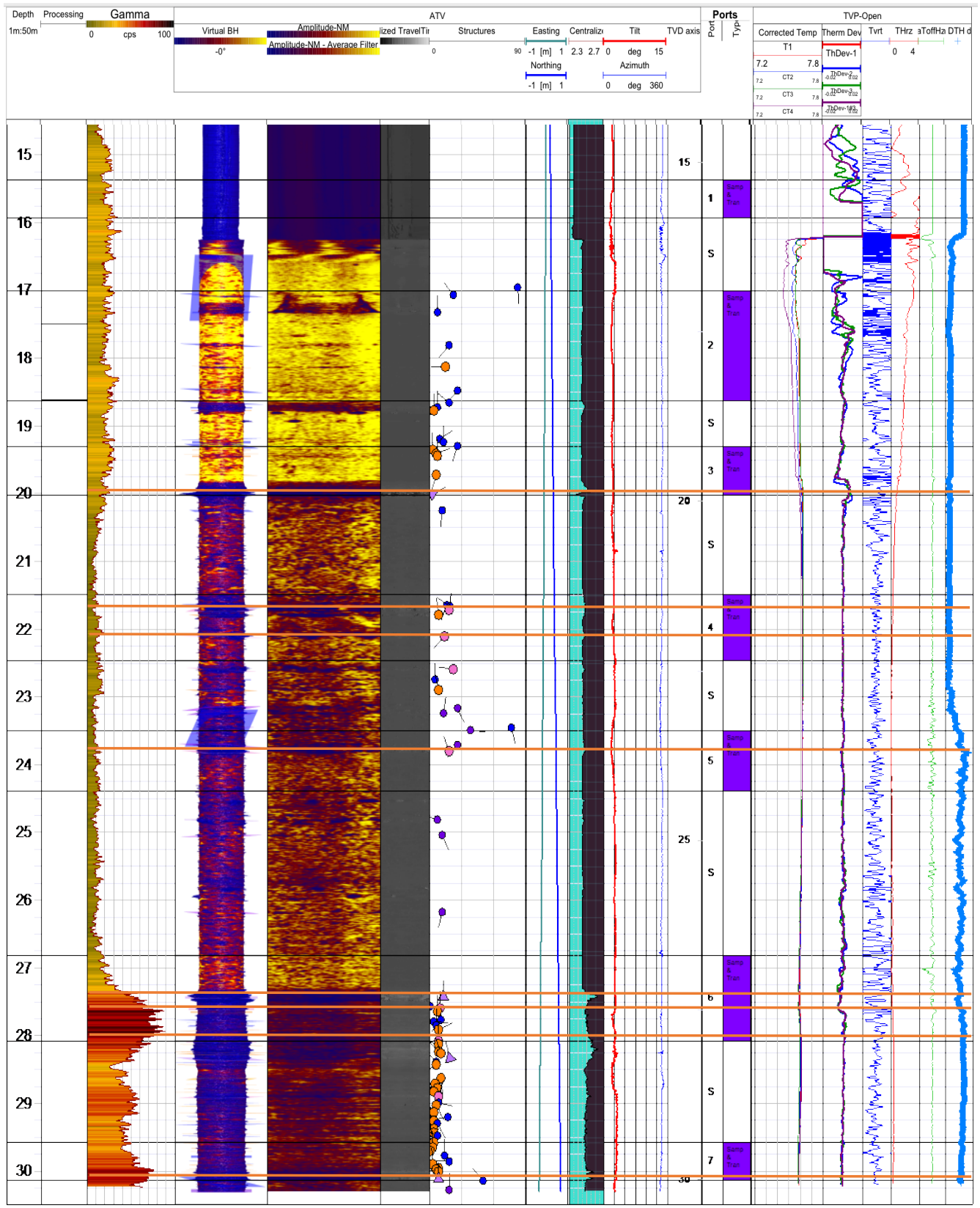

Figure 3. The identification of active fractures (indicated by orange horizontal lines) located in CMT ports from a geophysical data log.

\section{Results}

\subsection{Tracer Breakthrough Curves}

Lissamine tracer was first observed at approximately $3 \mathrm{~h}$ and $20 \mathrm{~min}$ after tracer application (Figure 4). Interestingly, the highest tracer concentrations and earliest breakthrough times were not observed in the shallowest ports, similar to findings indicated by Levison and Novakowski [45]; the highest concentrations were observed in the lower three ports, and the earliest arrival times occurred in ports 3 and 5. Port 2, the shallowest port below the water table, exhibited the lowest concentrations throughout the experiment, with three small peaks of $4.4,4.0$, and $1.7 \mathrm{mg} / \mathrm{L}$ occurring at $5 \mathrm{~h}, 8 \mathrm{~h}$, and $12 \mathrm{~h} 35 \mathrm{~min}$, respectively. In contrast, port 6 had three peaks of 86.9,50.9, and $18.5 \mathrm{mg} / \mathrm{L}$ occurring at $6 \mathrm{~h}, 8 \mathrm{~h}$, and $11 \mathrm{~h}$ $20 \mathrm{~min}$, respectively. Concentrations in port 7 surpassed those of port 6 , peaking later on in the experiment; a full breakthrough curve could not be obtained for this port due to the lower hydraulic conductivity of fractures isolated in this interval. Water samples had to be 
collected less frequently, and port 7 was purged dry without sufficient recovery rate for sampling by $20 \mathrm{~h}$.

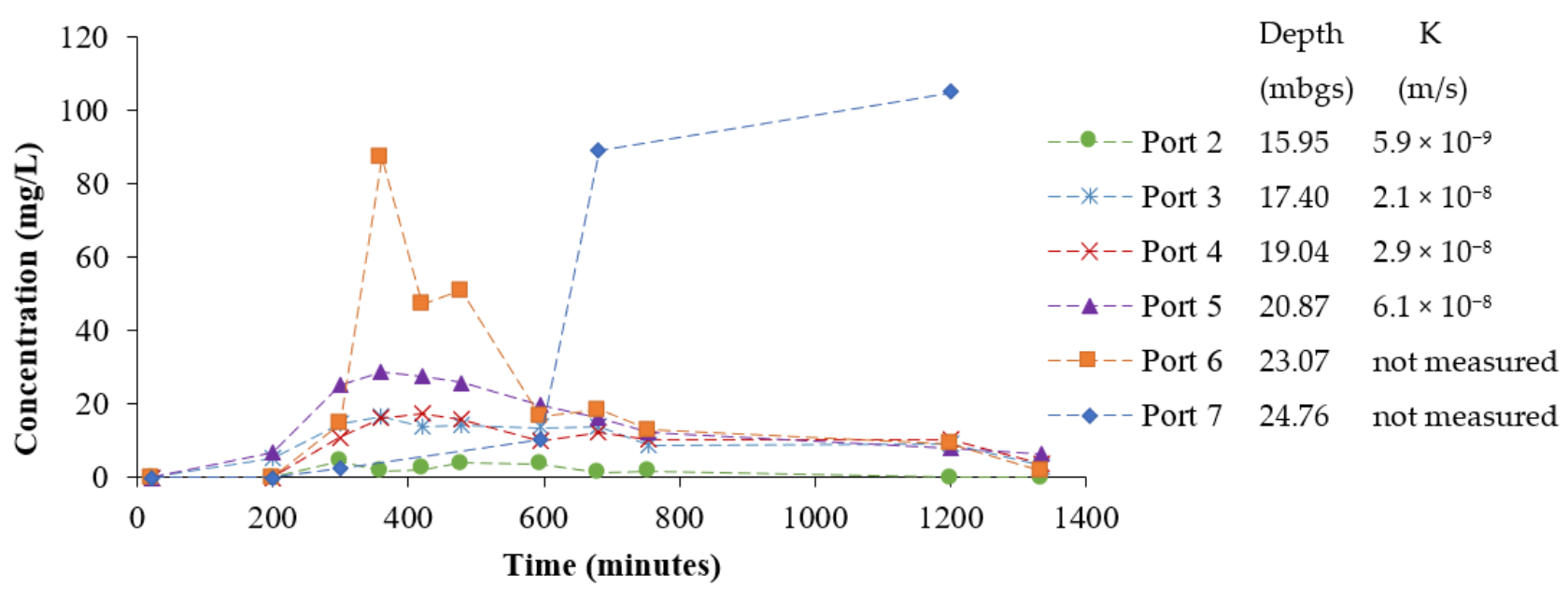

(a)

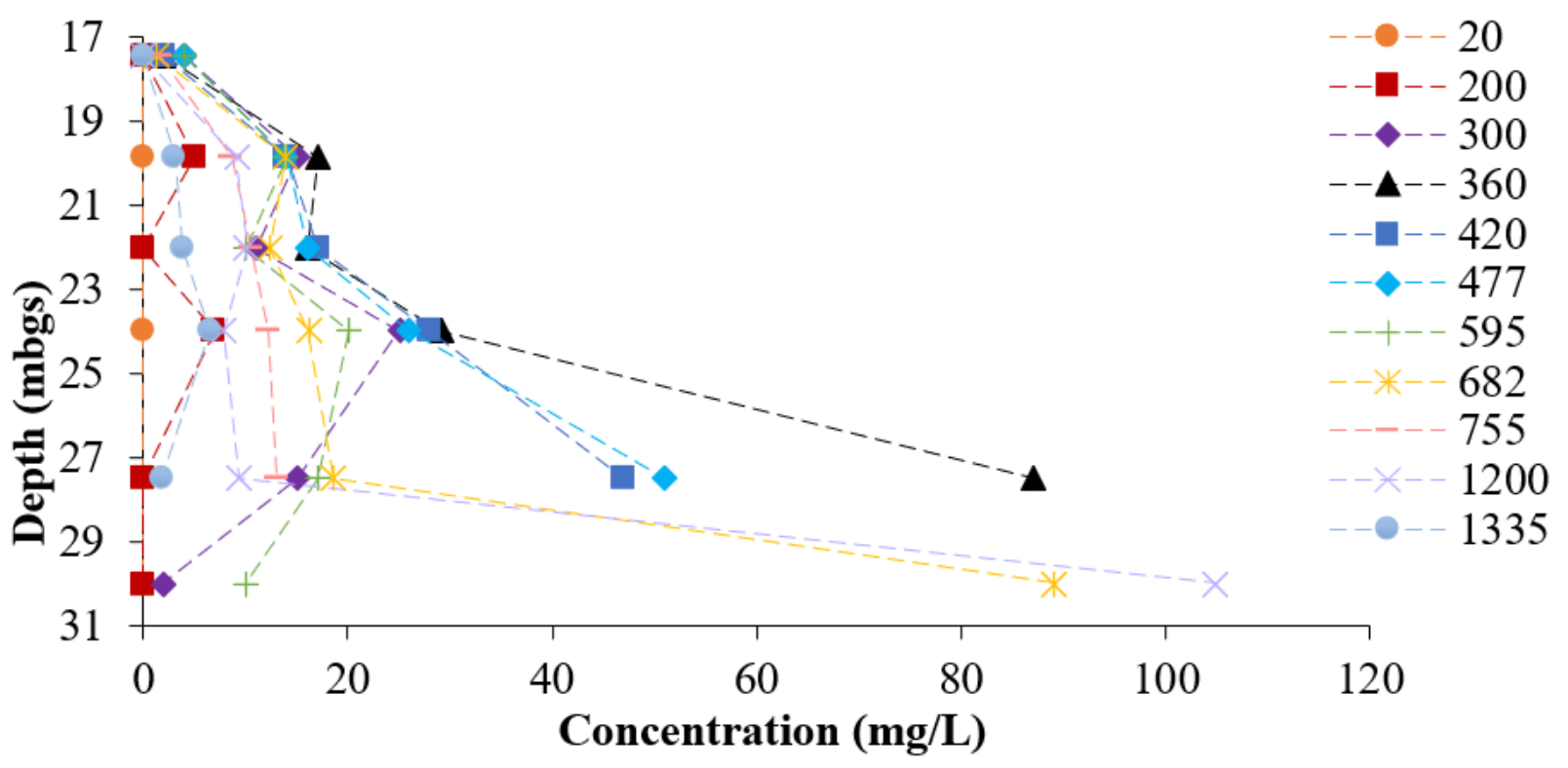

(b)

Figure 4. Lissamine Flavine FF concentrations as (a) breakthrough curves (with time, min) and (b) profiles (with depth), in ports 2 to 7 of a CMT multilevel monitoring system during a 24-h infiltration tracer experiment.

Most ports exhibited multiple peaks, which could indicate the effects of multiple fracture pathways contributing solute to the monitoring port at different times. All ports except port 7 reached their highest concentration peaks between $3 \mathrm{~h} 20 \mathrm{~min}$ and $7 \mathrm{~h}$ after tracer application. The appearance of the highest concentrations in lower ports demonstrates the complexity of fracture networks in sedimentary bedrock, the high vertical connectivity, and the high vertical component of the hydraulic gradient.

Artificial sweetener breakthrough curves (Figure 5) had some similarities to the Lissamine breakthrough curves. For example, some of the artificial sweetener breakthrough curves had multiple peaks, suggesting the influence of multiple fractures and pathways. Port 7 showed an increase in acesulfame concentration during the last hour of the test, 
indicating that the 24-h experiment period was also not long enough to provide a full breakthrough curve for this sweetener in this deepest port with lower hydraulic conductivity. Interestingly, shallower ports had concentration peaks near the end of the experiment, which was not the case with the Lissamine results. Ports 2 and 3 showed peaks in cyclamate concentration within the last two hours of the test.

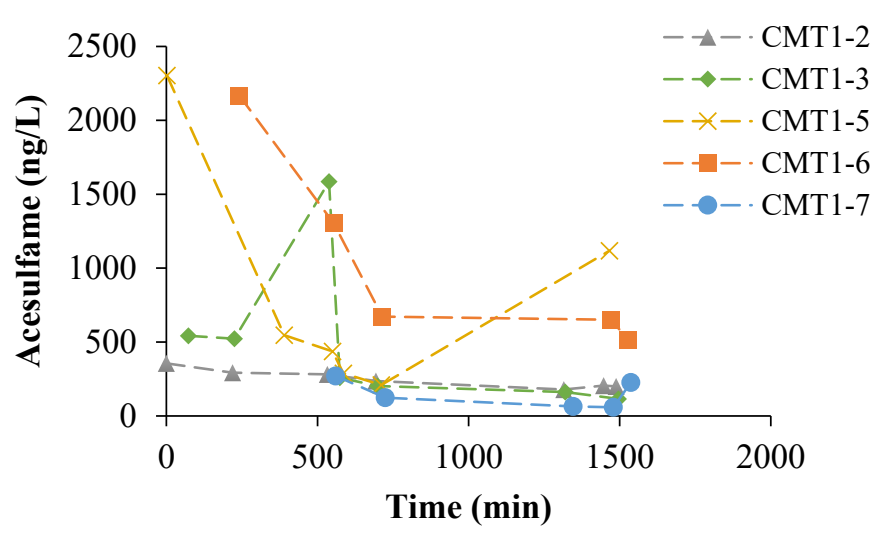

(a)

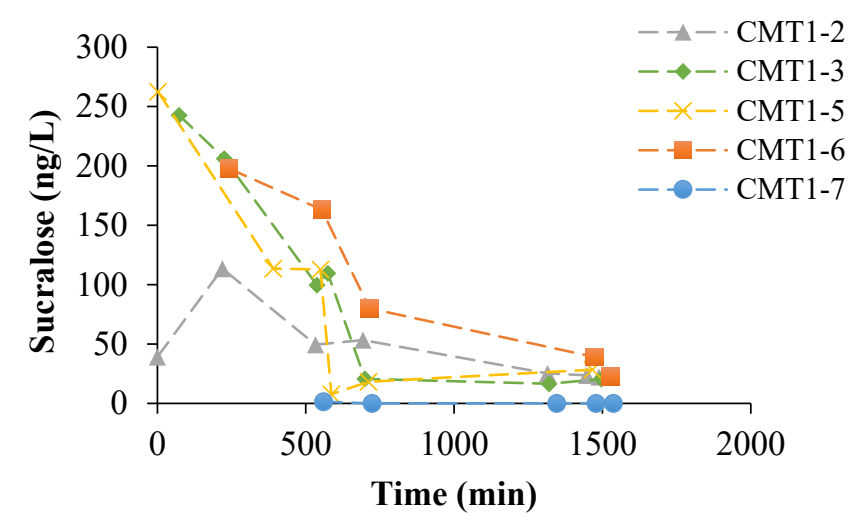

(c)

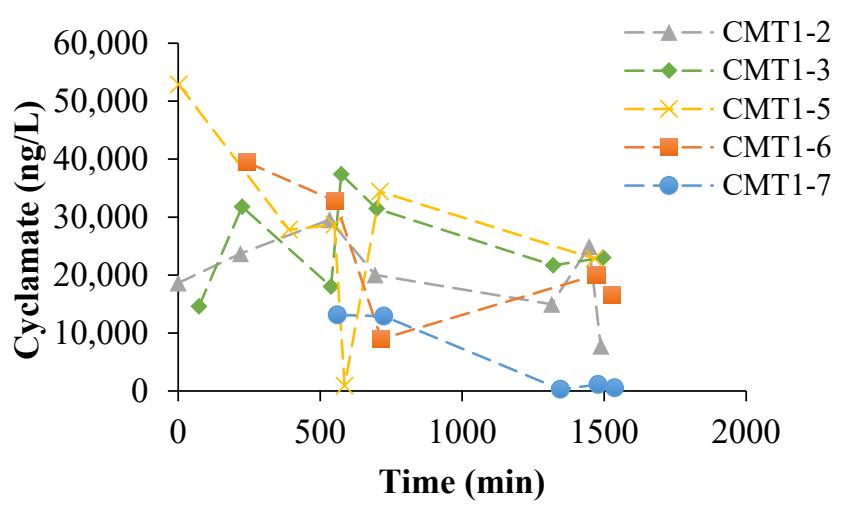

(e)

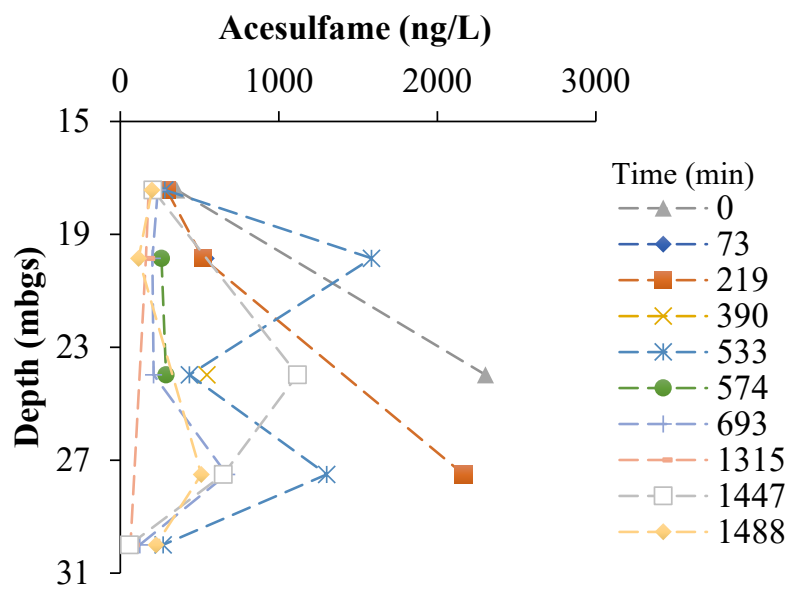

(b)

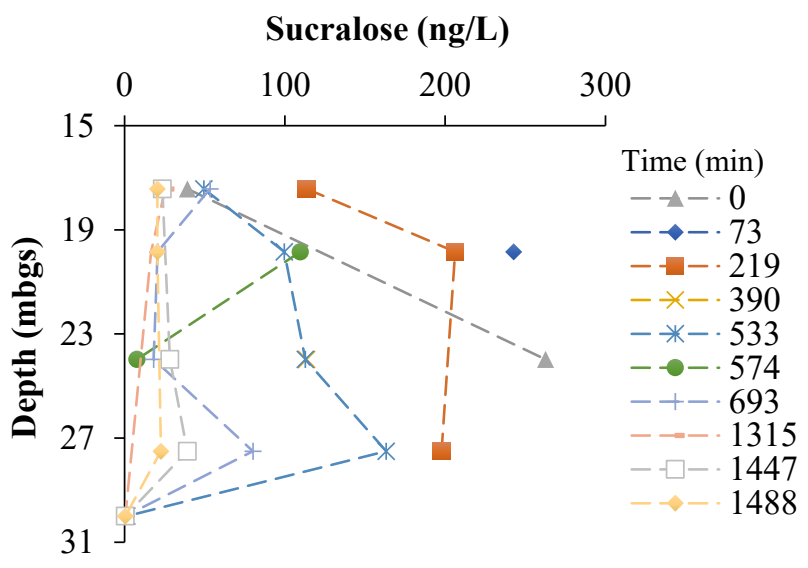

(d)

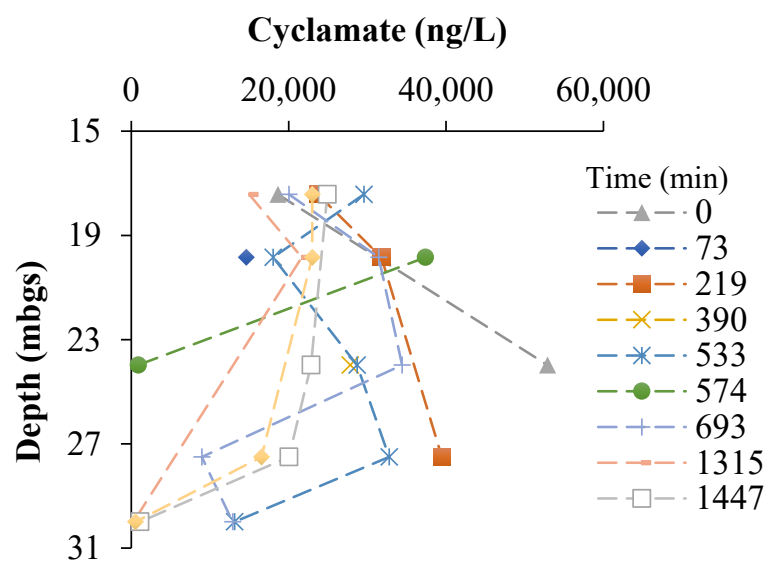

(f)

Figure 5. (a-f) Artificial sweetener breakthrough curves and profiles in a CMT multilevel monitoring system during a 24-h infiltration experiment. 
A full comparison between the two tracer experiments is hindered by the fact that elevated background concentrations of artificial sweeteners from the previous experiment conducted 20 November 2016 (seven days prior) had not moved out of the groundwater system and were still present at the outset of the present experiment. These background concentrations decreased over the course of the present experiment, and therefore could not be separated from the data to identify distinct tracer breakthrough times for the artificial sweeteners. However, background concentrations provided insight into the persistence of the three sweeteners in a fractured sedimentary bedrock system under natural conditions (i.e., no pumping). When normalized for the initial concentration of artificial sweetener applied to the septic bed seven days prior, $\mathrm{C} / \mathrm{C}_{0}$ concentrations ranged from $8 \times 10^{-7}$ to $5 \times 10^{-6}$ for acesulfame, $2 \times 10^{-6}$ to $1 \times 10^{-5}$ for sucralose, and $6 \times 10^{-5}$ to $2 \times 10^{-4}$ for cyclamate.

The three artificial sweeteners behaved somewhat differently from one another. Although similar initial quantities of acesulfame and sucralose were applied to the septic bed, acesulfame concentrations were at times an order-of-magnitude greater in the monitoring ports. This result corroborates the findings of other field-scale studies, which have found acesulfame to behave the most conservatively under field conditions [65-67,70]. Cyclamate concentrations were considerably higher than expected; concentrations observed in the ports relative to the initial concentration applied at surface were greater than those of sucralose. For example, the greatest cyclamate peaks arriving towards the end of the 24-h period were up to $3 \times 10^{-4 \%}$ of the initial concentration applied to the septic bed. In comparison, the highest acesulfame and sucralose peaks were $1 \times 10^{-3}$ and $5 \times 10^{-5} \%$ of the initial concentrations applied to the septic bed, respectively. Additionally, the elevated background concentrations of cyclamate were an order-of-magnitude greater than those of sucralose, and two orders-of-magnitude greater than those of acesulfame. These results suggest that cyclamate behaves more conservatively in the field, and that it may behave more conservatively in fractured sedimentary aquifers than in granular media. Studies that have examined artificial sweetener concentrations at the field scale in relation to their initial concentrations (e.g., by measuring initial concentrations in septic systems) have all been conducted in granular media $[15,67,68,73]$. However, the larger dose of cyclamate included in the tracer mix could have played a role in the elevated percentage remaining in the groundwater system; more research that attempts to constrain experiment variables in a field setting are required to better examine the behaviour of cyclamate in fractured sedimentary aquifer environments.

\subsection{Numerical Modeling}

No tracer was able to pass through the soil profile in the Hydrus 1D model when the effects of sorption were considered (i.e., when a $\mathrm{K}_{\mathrm{d}}$ greater than 0 was used). With Layer 1 and Layer 2 thicknesses of 60 and $90 \mathrm{~cm}$, respectively, and a $\mathrm{K}_{\mathrm{d}}$ of $0,1.3 \times 10^{-10} \mathrm{mg} / \mathrm{L}$ of tracer reached the bottom of the profile in $15 \mathrm{~h}$, which did not correspond to observations made in the field. Given that Lissamine was first detected in Port 3 by $t=3.33 \mathrm{~h}$ with a concentration of $5.2 \mathrm{mg} / \mathrm{L}$, solute was expected to reach the bottom of the profile in less than $3.33 \mathrm{~h}$ with a concentration greater than $5.2 \mathrm{mg} / \mathrm{L}$. Therefore, other conceptual models were considered that varied the thicknesses of Layers 1 and 2 . Three scenarios were considered in both Hydrus 1D and CRAFLUSH to explore the range of soil thicknesses and fracture apertures that would be required to produce a concentration of $5.2 \mathrm{mg} / \mathrm{L}$ at a distance of $34.85 \mathrm{~m}$ along the fracture in $3.33 \mathrm{~h}$ (Table 2; Figures 6-8). 
Table 2. Three solute transport scenarios through a septic bed and overburden below. Solute concentrations at the bottom of the soil profile were used as input concentrations in CRAFLUSH $[80,81]$. Scenarios 1 and 2 were modeled in Hydrus 1D [76].

\begin{tabular}{cccccc}
\hline Scenario & $\begin{array}{c}\text { Soil Residence } \\
\text { Time (min) }\end{array}$ & $\begin{array}{c}\text { Bedrock Residence } \\
\text { Time (min) }\end{array}$ & $\begin{array}{c}\text { Layer 1, Septic } \\
\text { Bed (cm) }\end{array}$ & $\begin{array}{c}\text { Layer 2, Gravelly } \\
\text { Clayey Silt (cm) }\end{array}$ & $\begin{array}{c}\text { Solute Concentration, } \\
\text { Bottom of Soil Profile (mg/L) }\end{array}$ \\
\hline \multirow{2}{*}{1} & & & & 12.7 & 5.2 \\
& 180 & & 60 & 2.8 & 100 \\
2 & 60 & 140 & 39.7 & 0 & 158.3 \\
3 & 0 & 200 & 31.5 & 0 & 5.2 \\
\hline
\end{tabular}

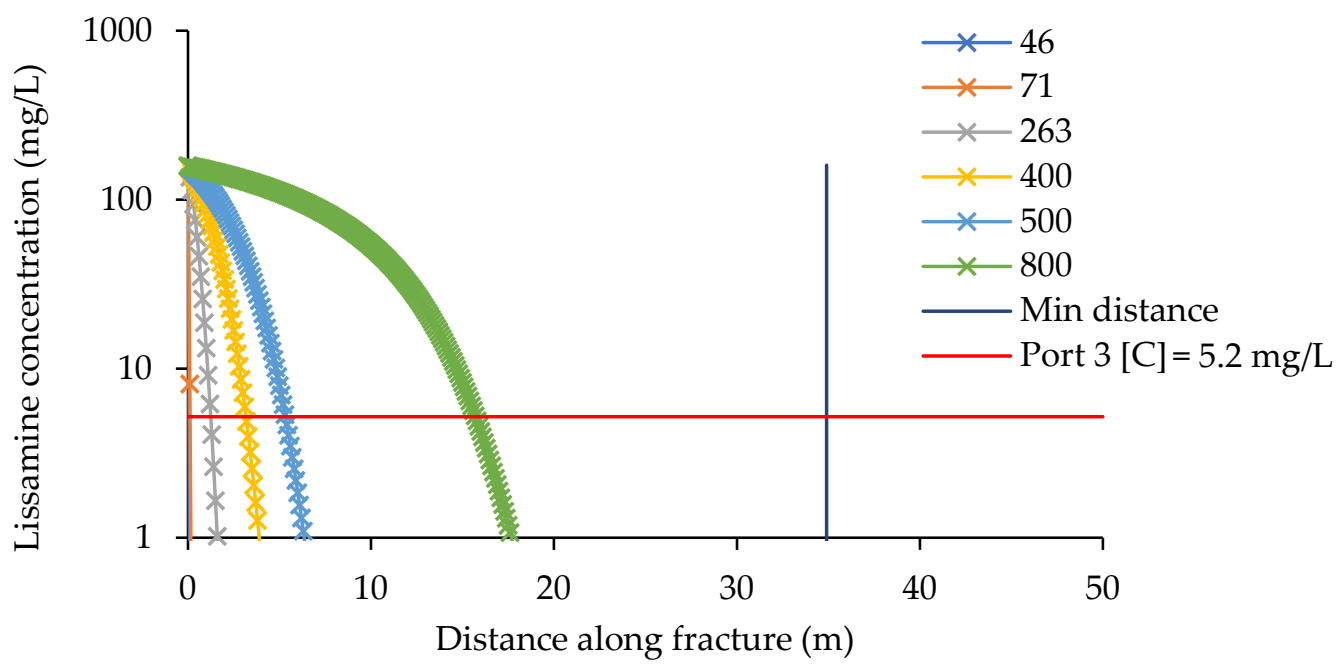

Figure 6. Scenario 1 CRAFLUSH outputs for a range of apertures $(46-800 \mu \mathrm{m})$ with an initial concentration corresponding to a septic bed thickness of $60 \mathrm{~cm}$ and soil layer thickness of $0 \mathrm{~cm}$ $\left(\mathrm{C}_{0}=158.3 \mathrm{mg} / \mathrm{L}\right)$.
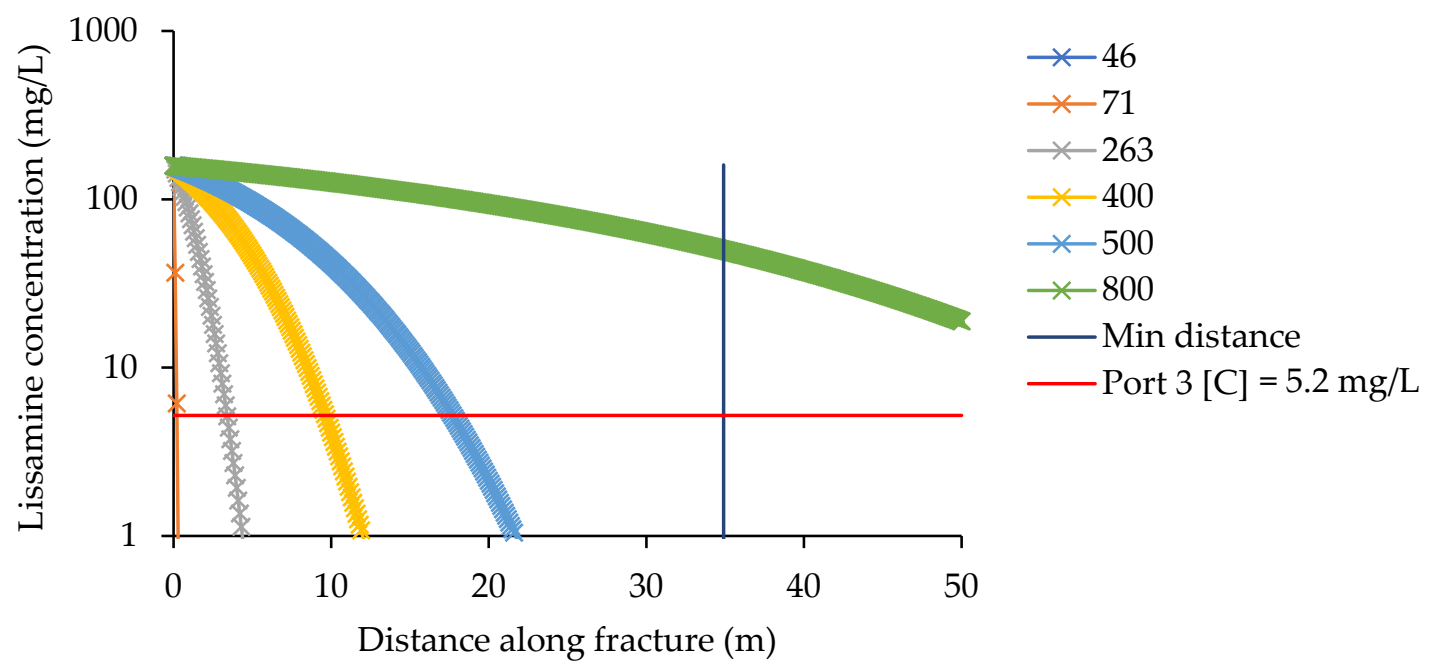

Figure 7. Scenario 2 CRAFLUSH outputs for a range of apertures $(46-800 \mu \mathrm{m})$ with an initial concentration corresponding to a septic bed thickness of $31.5 \mathrm{~cm}$ and soil layer thickness of $0 \mathrm{~cm}$ $\left(\mathrm{C}_{0}=100 \mathrm{mg} / \mathrm{L}\right)$. 


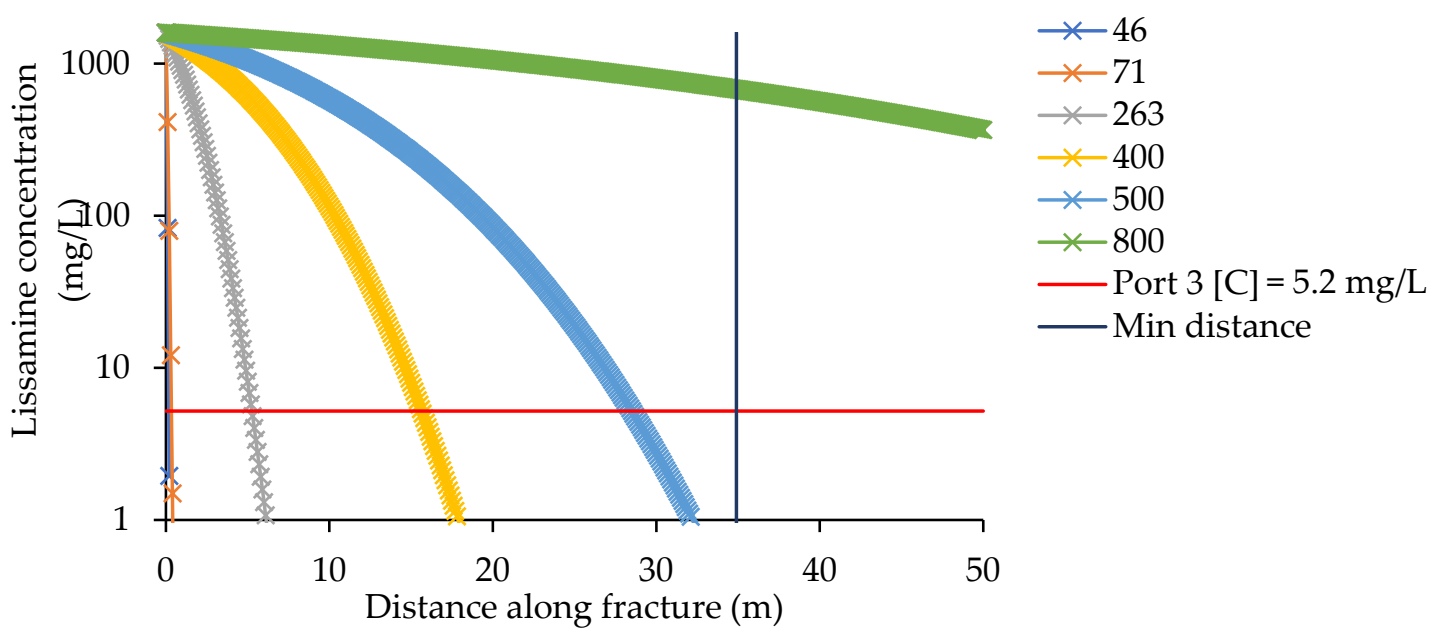

Figure 8. Scenario 3 CRAFLUSH outputs for a range of apertures $(46-800 \mu \mathrm{m})$ with an initial concentration corresponding to a septic bed thickness of $0 \mathrm{~cm}$ and soil layer thickness of $0 \mathrm{~cm}$ $\left(\mathrm{C}_{0}=1600 \mathrm{mg} / \mathrm{L}\right)$.

Scenario 1 did not correspond with field observations. If solute remained in the soil profile for $3 \mathrm{~h}$ and spent only $0.33 \mathrm{~h}$ in the fractured bedrock, no solute reached the minimum distance along the fractures (i.e., the CMT). In Scenario 2, in which solute traveled through the soil profile for $1 \mathrm{~h}$ and through the fractured bedrock for $2.33 \mathrm{~h}$, only a very large aperture $(800 \mu \mathrm{m})$ was able to transmit solute to the CMT. In Scenario 3, in which the solute was assumed to completely bypass the septic bed altogether and the full concentration was applied to the fractured bedrock, large apertures were still required to transmit solute to the CMT in $3.33 \mathrm{~h}$.

The aperture results from the model are an order-of-magnitude larger than most of the equivalent apertures calculated from the slug tests in individual ports (46 to $101 \mu \mathrm{m}$ ) and are on the same order-of-magnitude as the equivalent aperture generated by the pumping test on the open well $(263 \mu \mathrm{m})$ but are still substantially larger. These results may be influenced by the assumptions made in the model (e.g., fracture length to the CMT, fully saturated flow), and demonstrate the complexity of modeling fractured rock systems. While more information would be needed to improve the model of Lissamine transport through the subsurface, these results illustrate the ineffectiveness of the leaching bed at protecting the fractured sedimentary bedrock aquifer from contamination. Movement through the soil profile was likely extremely rapid, allowing most of the travel time to occur rapidly along preferential flow pathways within the fractured rock.

\section{Discussion}

The results of the two tracer experiments indicate that pathways connected solute from the septic bed to the CMT multilevel at multiple depths. Fluctuations in concentrations may therefore be attributed to the influence of the fracture network. The connectivity of fractures, which is influenced by fracture geometry controls the distribution and magnitude of hydraulic conductivity within the three-dimensional fracture network [85]. Solute concentration peaks occurred at different times, suggesting that preferential flow through multiple connected fractures with different attenuation along their pathways may be contributing solute from the septic bed to the CMT monitoring well. Given the short solute arrival times, it is likely that septic leachate is moving rapidly through the overburden before making its way into bedrock at the site. This rapid travel may be related to an improper septic bed design, such as a leaching bed located less than $900 \mathrm{~mm}$ above bedrock, as specified in the Ontario Building Code [79] or could be related to issues with the septic system construction. For example, in a study conducted by Alexander et al. [13], the septic tank and dosing chamber of a brand-new septic system were installed on a gravel 
layer, allowing leachate to "short-circuit" the leaching bed and enter the groundwater quickly. It may also be possible that fractures or macro-pathways that cause channeling exist in the thin soil layer below the septic bed, allowing leachate to move rapidly with little attenuation through connected pathways into the bedrock below. Once in the bedrock below, preferential flow paths in the fracture network allowed the solute to move rapidly to the CMT multilevel, contributing to the short arrival times.

These results highlight that in general, conventional septic systems are poorly suited to fractured sedimentary bedrock environments, especially with thin overburden soils or soils with rapid flow. This is particularly emphasized by the fact that the CMT multilevel was installed in a drinking water well (now unused) located $15 \mathrm{~m}$ from the septic bed, in accordance with established setback distances [86]. Septic system malfunctions, which can happen to new and older septic systems alike and are not always visible from the surface, may cause rapid and widespread contamination of groundwater in fractured sedimentary rock settings [69]. It is noteworthy that rapid transport was observed with solute tracers that are much more susceptible to attenuation in fractured sedimentary rock and clayey soils, and pathogens such as viruses and E. coli are even more likely to travel rapidly in such hydrogeologic systems [87]. Furthermore, conventional septic systems are problematic for First Nations that are unable to ensure the regular maintenance, replacement, and monitoring of septic systems. In the provincial source water protection plan for the area near Neyaashiinigmiing reserve, small septic systems located in vulnerable areas are required to be removed and replaced with a connection to a municipal sewer system, and all new builds are required to establish municipal sewer connections [88]. However, connecting to municipal sewer systems is not an option for rural First Nations such as the Chippewas of Nawash, and funding is generally not available to construct wastewater treatment plants and sewer systems for these small, dispersed populations. Rural, non-First Nation residents are faced with the same predicaments.

A recent study by Hamilton et al. [89] outlined extensive areas in Southern Ontario where subsurface karst is connected to the surface, resulting in rapid recharge. Hamilton et al. greatly extended the areas known to be highly vulnerable due to surface-connected karst features, including the area near the boundary of Neyaashiinigmiing reserve. While no karst features have been reported on the reserve [50], the rapid arrival of tracers in the CMT may indicate that groundwater flow is influenced by nearby subsurface karst. The results of this research and the study conducted by Hamilton et al. [89] suggest that more stringent regulations are needed for the design and use of septic systems in karst or non-karst fractured rock environments. In the source water protection plan for the Saugeen, Grey Sauble, and Northern Bruce Peninsula areas, it is recommended that the Ontario Building Code "require that advanced septic systems be required for new installations in vulnerable areas where an on-site sewage system is or would be a significant drinking water threat" [88] (pp. 6-22). It is recommended here that the definition of "drinking water threat" be extended beyond the areas that impact municipal drinking water sources to include areas of rapid recharge that may impact the drinking water sources of rural and First Nation residents, such as those areas outlined by Hamilton et al. [89].

\section{Conclusions}

Two successful qualitative solute tracer experiments were performed, demonstrating that multiple connected preferential pathways exist between the septic bed and the CMT multilevel monitoring system, and that travel from near surface leach fields to depth can be extremely rapid in fractured sedimentary bedrock aquifers with thin overburden. Lissamine Flavine FF and all three artificial sweeteners applied to the surface of the septic bed-acesulfame, sucralose, and cyclamate-were observed at multiple depths in the CMT multilevel.

Elevated tracer concentrations in deeper multilevel ports highlighted the complexity of fracture networks in sedimentary bedrock. Numerical and analytical analyses of the transport of Lissamine from the septic bed to depth suggested that the septic bed and 
overburden below (if any is in place) is inadequate for attenuating solutes and protecting the fractured rock aquifer, despite the suitability of the design from a best practices perspective and the lack of visible signs that the septic system is malfunctioning. This suggests the need for performance checks on septic systems to address different hydrogeologic environments known for rapid recharge to groundwater. Additionally, more studies are needed that consider a variety of subsurface data to effectively model the transport of tracers from the septic bed to depth in the fractured sedimentary aquifer.

The rapid transport of septic leachate to groundwater is problematic for First Nations communities with aging and malfunctioning septic systems. More funding is required for the maintenance and replacement of septic systems on reserves, and in particular, special consideration should be given to First Nation communities situated above vulnerable fractured rock aquifers. Currently, federal funding in Canada for the construction of wastewater treatment infrastructure on reserves is limited [23], which is particularly problematic for communities with reserve residents that are unable to afford the maintenance of their septic systems. For communities that are able to replace aging septic systems, alternative decentralized wastewater treatment technologies should be considered (e.g., advanced septic systems; composting toilets) - particularly for communities located in areas with rapid recharge rates to the groundwater zone that may be influenced by discrete fracture flow and/or karst features. More stringent regulations, and the means to implement them, are needed for the design and use of septic systems in fractured rock environments.

Author Contributions: Conceptualization, R.M., J.L., B.P. and E.M.; methodology, R.M., J.L., B.P. and E.M.; software, R.M. and J.L.; validation, R.M.; formal analysis, R.M.; investigation, R.M.; resources, J.L. and E.M.; data curation, R.M.; writing—original draft preparation, R.M.; writing-review and editing, R.M., J.L., B.P. and E.M.; visualization, R.M.; supervision, J.L. and E.M.; project administration, R.M.; funding acquisition, R.M., J.L. and E.M. All authors have read and agreed to the published version of the manuscript.

Funding: This research was funded by the Royal Bank of Canada (RBC) Ontario Field Resource Program (Grant Number 052636), the Natural Sciences and Engineering Research Council of Canada (NSERC) Alexander Graham Bell Canada Graduate Scholarships Doctoral Program, the RES'EAUWaterNET National Centre of Excellence (NSERC Grant Sub-award Q/UBC 11R17970), and the Ontario Graduate Scholarship Program.

Institutional Review Board Statement: Not applicable.

Informed Consent Statement: Not applicable.

Data Availability Statement: Data supporting the reported results of this study can be found in Rachael Marshall's Ph.D. dissertation, which is available at: https: / / atrium.lib.uoguelph.ca/xmlui / handle/10214/14716 (accessed on 8 February 2022).

Acknowledgments: The authors would like to deeply thank the Chippewas of Nawash Unceded First Nation for partnering with the University of Guelph in this research. Thank you in particular to M. Desjardine, the Nawash Water Protection Committee, and to the community members who granted us access to their wells and septic systems. Thank you to E. Brown, S. Gardner, E. Persaud, C. Klabunde, J. Miller, and others for support conducting fieldwork. Thank you to the Morwick G360 Groundwater Research Institute for support with the collection, analysis, and interpretation of down-hole geophysical data, and to $\mathrm{C}$. Metcalfe for conducting the artificial sweetener analysis at Trent University.

Conflicts of Interest: The authors declare no conflict of interest. The funders had no role in the design of the study; in the collection, analyses, or interpretation of data; in the writing of the manuscript, or in the decision to publish the results.

\section{References}

1. Lea, C.K.; Petersen, C.; Sowells, C.W.; Ables, S. Clean water everywhere: A look at source water assessment and protection across the United States. In Proceedings of the World Environment and Water Resources Congress, Providence, RI, USA, 16-20 May 2010.

2. Cassin, J. Nature-based solutions for source water protection in North America. In Nature-Based Solutions and Water Security; Cassin, J., Matthews, J.H., Lopez Gunn, E., Eds.; Elsevier: Amsterdam, The Netherlands, 2021; pp. $179-214$. 
3. Cyr-Gagnon, J.; Rodriguez, M.J. Optimizing data management for municipal source water protection. Land Use Pol. 2021, 100, 103788. [CrossRef]

4. Kumar, V.; Mishra, N. Sustainable watering of the watershed: A qualitative analysis of the Choral River Revival Project in Narmada Basin, India. Dev. Pract. 2021. [CrossRef]

5. Marshall, R.; Desjardine, M.; Levison, J.; Anderson, K.; McBean, E. Moving towards effective First Nations' source water protection: Barriers, opportunities, and a framework. Water 2020, 12, 2957. [CrossRef]

6. Marshall, R.E.; Levison, J.K.; McBean, E.A.; Brown, E.; Harper, S.L. Source water protection programs and Indigenous communities in Canada and the United States: A scoping review. J. Hydrol. 2018, 562, 358-370. [CrossRef]

7. UN Department of Economic and Social Affairs. Sustainable Development Goals Report; United Nations: New York, NY, USA, 2017.

8. Duda, A.M.; Cromartie, K.D. Coastal Pollution from Septic Tank Drainfields. J. Environ. Eng. 1982, 108, 1265-1279. [CrossRef]

9. Yates, M.V. Septic tank density and ground-water contamination. Ground Water 1985, 23, 586-591. [CrossRef]

10. Chen, M. Pollution of Groundwater by Nutrients and Fecal Coliforms from Lakeshore Septic Tank Systems. Water Air Soil Pollut. 1988, 37, 407-417. [CrossRef]

11. Hatt, B.E.; Fletcher, T.D.; Walsh, C.J.; Taylor, S.L. The influence of Urban Density and Drainage on the Concentrations and Loads of Pollutants in Small Streams. Environ. Manag. 2004, 34, 112-124. [CrossRef]

12. Landre, B.; Lewandowski, S.; Makarewicz, J.C.; Terninko, J.; Thorndike, E. Lake Ontario Coastal Initiative Action Agenda; Technical report 82; SUNY Brockport: Brockport, NY, USA, 2006.

13. Alexander, S.C.; Alexander, E.C., Jr.; Green, J.A.; Schuster, W.E.; Forest, B. Dye trace study of a new septic system in Door County, Wisconsin. In Sinkholes and the Engineering and Environmental Impacts of Karst, Proceedings of the 11th Multidisciplinary Conference, Tallahassee, FL, USA, 22-26 September 2008; ASCE/GI Geotechnical Special Publication No 183; Yuhr, L.B., Alexander, E.C., Jr., Beck, B.F., Eds.; American Society of Civil Engineers: Reston, VA, USA, 2008; pp. 495-504.

14. Borchardt, M.A.; Bradbury, K.R.; Alexander, E.C.; Kolberg, R.J.; Alexander, S.C.; Archer, J.R.; Braatz, L.A.; Forest, B.M.; Green, J.A.; Spencer, S.K. Norovirus Outbreak Caused by a New Septic System in a Dolomite Aquifer. Ground Water 2011, $49,85-97$. [CrossRef]

15. Robertson, W.D.; Van Stempvoort, D.R.; Solomon, D.K.; Homewood, J.; Brown, S.J.; Spoelstra, J.; Schiff, S.L. Persistence of artificial sweeteners in a 15-year-old septic system plume. J. Hydrol. 2013, 477, 43-54. [CrossRef]

16. Spoelstra, J.; Senger, N.D.; Schiff, S.L. Artificial sweeteners reveal septic system effluent in rural groundwater. J. Environ. Qual. 2017, 46, 1434-1443. [CrossRef] [PubMed]

17. Mutch, R.D.; Scott, J.I.; Wilson, D.J. Cleanup of fractured rock aquifers: Implications of matrix diffusion. Environ. Monit. Assess. 1993, 24, 45-70. [CrossRef] [PubMed]

18. Goldstein, K.J.; Vitolins, A.R.; Navon, D.; Parker, B.L.; Chapman, S.; Anderson, G.A. Characterization and pilot-scale studies for chemical oxidation remediation of fractured shale. Remediation 2004, 14, 19-37. [CrossRef]

19. Parker, B.L.; Chapman, S.W.; Cherry, J.A. Plume persistence in fractured sedimentary rock after source zone removal. Ground Water 2010, 48, 799-803.

20. Chapman, S.W.; Parker, B.L. Plume persistence due to aquitard back diffusion following dense nonaqueous phase liquid source removal or isolation. Water Resour. Res. 2005, 41. [CrossRef]

21. Chapman, S.W.; Parker, B.L.; Cherry, J.A.; McDonald, S.D.; Goldstein, K.J.; Frederick, J.J.; St Germain, D.J.; Cutt, D.M.; Williams, C.E. Combined MODFLOW-FRACTRAN Application to Assess Chlorinated Solvent Transport and Remediation in Fractured Sedimentary Rock. Remediation 2013, 23, 7-35. [CrossRef]

22. Neegan Burnside Ltd. National Assessment of First Nations Water and Wastewater Systems; Department of Indian Affairs and Northern Development: Orangeville, ON, Canada, 2011.

23. McCullough, J.; Farahbakhsh, K. Square peg, round hole: First Nations drinking water infrastructure and federal policies, programs, and processes. Int. Indig. Policy J. 2012, 3. [CrossRef]

24. Province of Ontario. Services Improvement Act; Schedule B; Legislative Assembly of Ontario: Toronto, ON, Canada, 1997.

25. Kozuskanich, J.C.; Novakowski, K.S.; Anderson, B.C.; Crowe, A.S.; Balakrishnan, V.K. Anthropogenic impacts on a bedrock aquifer at the village scale. Ground Water 2014, 52, 474-486. [CrossRef]

26. Novakowski, K.; Liss, S.; Sleep, B. Canadian Water Network. Pathogens in Bedrock Aquifers-A Detailed Study of the Presence and Transport of Pathogens in Urbanized Settings Having On-Site Waste Disposal and Private Bedrock Wells. 2013. Available online: http:/ / www.cwn-rce.ca/project-library/project/pathogens-in-bedrock-aquifers-a-detailed-study-of-the-presenceand-transport-of-pathogens-in-urbanized-settings-having-on-site-waste-disposal-and-private-bedrock-wells- (accessed on 16 October 2018)

27. DeBorde, D.C.; Woessner, W.W.; Lauerman, B.; Ball, P.N. Virus occurrence and transport in a school septic system and unconfined aquifer. Ground Water 1998, 36, 825-834. [CrossRef]

28. Rose, J.B.; Griffin, D.W.; Nicosia, L.W. Virus transport: From septic tanks to coastal waters. Small Flows 2000, 1, 20-23.

29. Darby, J.L.; Leverenz, H. Virus, Phosphorus, and Nitrogen Removal in Onsite Wastewater Treatment Processes; Technical Completion Report Project no. W-953; University of California Water Resources Center: Riverside, CA, USA, 2004.

30. Wilhelm, S.R.; Schiff, S.L.; Robertson, W.D. Chemical fate and transport in a domestic septic system: Unsaturated and saturated zone geochemistry. Environ. Toxicol. Chem. 1994, 13, 13,193-203. [CrossRef] 
31. Aravena, R.; Robertson, W.D. Use of multiple isotope tracers to evaluate denitrification in ground water: Study of nitrate from a large flux septic system plume. Ground Water 1998, 36, 975-982. [CrossRef]

32. Hinkle, S.R.; Bohlke, J.K.; Fisher, L.H. Mass balance and isotope effects during nitrogen transport through septic tank systems with packedbed (sand) filters. Sci. Total Environ. 2008, 407, 324-332. [CrossRef] [PubMed]

33. Seiler, R.L.; Zaugg, S.D.; Thomas, J.M.; Howcroft, D.L. Caffeine and pharmaceuticals as indicators of waste water contamination in wells. Ground Water 1999, 37, 405-410. [CrossRef]

34. Godfrey, E.; Woessner, W.W.; Benotti, M.J. Pharmaceuticals in onsite sewage effluent and ground water, western Montana. Ground Water 2007, 45, 263-271. [CrossRef]

35. Carrara, C.; Ptacek, C.J.; Robertson, W.D.; Blowes, D.W.; Moncur, M.C.; Sverko, E.; Backus, S. Fate of pharmaceutical and trace organic compounds in three septic system plumes. Environ. Sci. Technol. 2008, 42, 2805-2811. [CrossRef]

36. Harden, H.S.; Chanton, J.P.; Rose, J.B.; John, D.E.; Hooks, M.E. Comparison of sulfur hexafluoride, fluorescein and rhodamine dyes and the bacteriophage PRD-1 in tracing subsurface flow. J. Hydrol. 2003, 277, 100-115. [CrossRef]

37. Richards, S.; Paterson, E.; Withers, P.J.A.; Stutter, M. Septic tank discharges as multi-pollutant hotspots in catchments. Sci. Tot. Environ. 2016, 542 Pt A, 854-863. [CrossRef]

38. Black, J.H.; Kipp, K.L. Movement of tracers through dual-porosity media-Experiments and modelling in the Cretaceous Chalk, England. J. Hydrol. 1983, 62, 287-312. [CrossRef]

39. Liu, H.-H.; Haukwa, C.B.; Ahlers, C.F.; Bodvarsson, G.S.; Flint, A.L.; Guertal, W.B. Modeling flow and transport in unsaturated fractured rock: An evaluation of the continuum approach. J. Contam. Hydrol. 2003, 62-63, 173-188. [CrossRef]

40. Kim, J.G.; Lee, G.H.; Lee, J.S.; Chon, C.M.; Kim, T.H.; Ha, K. Infiltration pattern in a regolith-fractured bedrock profile: Field observation of a dye stain pattern. Hydrol. Processes. 2006, 20, 241-250. [CrossRef]

41. Duke, C.L.; Roback, R.C.; Reimus, P.W.; Bowman, R.S.; McLing, T.L.; Baker, K.E.; Hull, L.C. Elucidation of flow and transport processes in a variably saturated system of interlayered sediment and fractured rock using tracer tests. Vad. Zone J. 2007, 6 855-867. [CrossRef]

42. Legout, C.; Molenat, J.; Aquilina, L.; Gascuel-Odoux, C.; Faucheux, M.; Fauvel, Y.; Bariac, T. Solute transfer in the unsaturated zone-groundwater continuum of a headwater catchment. J. Hydrol. 2007, 332, 427-441. [CrossRef]

43. Lu, G.; Liu, H.H.; Salve, R. Long term infiltration and tracer transport in fractured rocks: Field observations and model analyses. J. Hydrol. 2011, 396, 33-48. [CrossRef]

44. Rugh, D.F.; Burbey, T.J. Using saline tracers to evaluate preferential recharge in fractured rocks, Floyd County, Virginia, USA Hydrogeol. J. 2008, 16, 251-262. [CrossRef]

45. Levison, J.K.; Novakowski, K.S. Rapid transport from the subsurface to wells in fractured rock: A unique infiltration tracer experiment. J. Contam. Hydrol. 2012, 131, 29-38. [CrossRef]

46. Panno, S.V.; Hackley, K.C.; Hwang, H.H.; Greenberg, S.E.; Krapac, I.G.; Landsberger, S.; O'Kelly, D.J. Characterization and identification of $\mathrm{Na}-\mathrm{Cl}$ sources in groundwater. Ground Water. 2006, 44, 176-187. [CrossRef]

47. Murray, K.E.; Straud, D.R.; Hammond, W.W. Characterizing groundwater flow in a faulted karst system using optical brighteners from septic systems as tracers. Environ. Geol. 2007, 53, 769-776. [CrossRef]

48. Katz, B.G.; Griffin, D.W.; McMahon, P.B.; Harden, H.; Wade, E.; Hicks, R.W.; Chanton, J. Fate of effluent-borne contaminants beneath septic tank drainfields overlying a karst aquifer. J. Environ. Qual. 2010, 39, 1181-1195. [CrossRef]

49. Harden, H.S.; Roeder, E.; Hooks, M.; Chanton, J.P. Evaluation of onsite sewage treatment and disposal systems in shallow karst terrain. Water Res. 2008, 42, 2585-2597. [CrossRef]

50. Genivar. Water Feasibility Study; Draft Report; Genivar Inc.: Owen Sound, ON, USA, 2011.

51. Armstrong, D.K. Paleozoic Geology of the Central Bruce Peninsula (Ontario Geological Survey Open File Report 5856); Queen's Printer for Ontario: Kingston, ON, Canada, 1993.

52. Brunton, F.; Brintnell, C.; Jin, J.; Bancroft, A. Stratigraphic architecture of the Lockport Group in Ontario and Michigan-A new interpretation of early Silurian 'basin geometries' \& 'Guelph pinnacle reefs'. In Proceedings of the Annual Conference of the Ontario Petroleum Institute, Niagara Falls, ON, Canada, 4-6 November 2013.

53. Moench, A.F. Flow to a well of finite diameter in a homogeneous, anisotropic water table aquifer. Water Resour. Res. 1997, 33, 1397-1407. [CrossRef]

54. Barker, J.A.; Black, J.H. Slug tests in fissured aquifers. Water Resour. Res. 1983, 19, 1558-1564. [CrossRef]

55. Witherspoon, P.A.; Wang, J.S.Y.; Iwai, K.; Gale, J.E. Validity of cubic law for fluid flow in a deformable rock fracture. Water Resour. Res. 1980, 16, 1016-1024. [CrossRef]

56. Black, C.A. Methods of Soil Analysis: Part I Physical and Mineralogical Properties; American Society of Agronomy: Madison, WI, USA, 1965.

57. Smith, R.T.; Atkinson, K. Techniques in Pedology: A Handbook for Environmental and Resource Studies; Paul Elec: London, UK, 1975; p. 213.

58. Smart, P.L.; Smith, D.I. Water tracing in tropical regions, the use of fluorometric techniques in Jamaica. J. Hydrol. 1976, 30, 179-195. [CrossRef]

59. Field, M.S.; Wilhelm, R.G.; Quinlan, J.F.; Aley, T.J. An assessment of the potential adverse properties of fluorescent tracer dyes used for groundwater tracing. Environ. Monit. Assess. 1995, 38, 75-96. [CrossRef]

60. Smart, P.L.; Laidlaw, M.S. An evaluation of some fluorescent dyes for water tracing. Water Resour. Res. 1977, 13, 15-33. [CrossRef] 
61. Smettem, K.R.J.; Trudgill, S.T. An evaluation of some fluorescent and non-fluorescent dyes in the identification of water transmission routes in soils. Eur. J. Soil Sci. 1983, 34, 45-56. [CrossRef]

62. Trudgill, S.T. Soil water dye tracing, with special reference to the use of Rhodamine WT, Lissamine FF and Amino G Acid. Hydrol. Process. 1987, 1, 149-170. [CrossRef]

63. Lapcevic, P.A.; Novakowski, K.S.; Sudicky, E.A. The interpretation of a tracer experiment conducted in a single fracture under conditions of natural groundwater flow. Water Resour. Res. 1999, 35, 2301-2312. [CrossRef]

64. Novakowski, K.S.; Bickerton, G.; Lapcevic, P. Interpretation of injection-withdrawal tracer experiments conducted between two wells in a large single fracture. J. Contam. Hydrol. 2004, 73, 227-247. [CrossRef]

65. Buerge, I.J.; Has-Rudolf, B.; Kahle, M.; Müller, M.D.; Poiger, T. Ubiquitous occurrence of the artificial sweetener acesulfame in the aquatic environment: An ideal chemical marker of domestic wastewater in groundwater. Environ. Sci. Technol. 2009, 43, 4381-4385. [CrossRef] [PubMed]

66. Scheurer, M.; Brauch, H.-J.; Lange, F.T. Analysis and occurrence of seven artificial sweeteners in German waste water and surface water and in soil aquifer treatment (SAT). Anal. Bioanal. Chem. 2009, 394, 1585-1594. [CrossRef] [PubMed]

67. Van Stempvoort, D.R.; Roy, J.W.; Brown, S.J.; Bickerton, G. Artificial sweeteners as potential tracers in groundwater in urban environments. J. Hydrol. 2011, 401, 126-133. [CrossRef]

68. Van Stempvoort, D.R.; Robertson, W.D.; Brown, S.J. Artificial sweeteners in a large septic plume. Groundw. Monit. Remed. 2011, 31, 95-102. [CrossRef]

69. Buerge, I.J.; Keller, M.; Buser, H.R.; Muller, M.D.; Poiger, T. Saccharin and other artificial sweeteners in soils: Estimated inputs from agriculture and households, degradation, and leaching to groundwater. Environ. Sci. Technol. 2011, 45, 615-621. [CrossRef] [PubMed]

70. Wolf, L.; Zwiener, C.; Zemann, M. Tracking artificial sweeteners and pharmaceuticals introduced into urban groundwater by leaking sewer networks. Sci. Total Environ. 2012, 403, 8-19. [CrossRef] [PubMed]

71. Ens, W.; Senner, F.; Gygax, B.; Schlotterbeck, G. Development, validation, and application of a novel LC-MS/MS trace analysis method for simultaneous quantification of seven iodinated X-ray contrast media and three artificial sweeteners in surface, ground, and drinking water. Anal. Bioanal. Chem. 2014, 406, 2789-2798. [CrossRef] [PubMed]

72. Snider, D.M.; Roy, J.W.; Robertson, W.D.; Garda, D.I.; Spoelstra, J. Concentrations of artificial sweeteners and their rations with nutrients in septic system wastewater. Groundwat. Monit. Remed. 2017, 37, 94-102. [CrossRef]

73. Robertson, W.D.; Van Stempvoort, D.R.; Spoelstra, J.S.; Brown, S.J.; Schiff, S.L. Degradation of sucralose in groundwater and implications for age dating contaminated groundwater. Water Res. 2016, 88, 653-660. [CrossRef]

74. Van Stempvoort, D.R.; Brown, S.J.; Spoelstra, J.; Garda, D.; Roberston, W.D.; Smyth, S.A. Variable persistence of artificial sweeteners during wastewater treatment: Implications for future use as tracers. Water Res. 2020, 184, 116124. [CrossRef]

75. Scheurer, M.; Storck, F.R.; Brauch, H.-J.; Lange, F.T. Performance of conventional multi-barrier drinking water treatment plants for the removal of four artificial sweeteners. Water Resour. 2010, 44, 3573-3584. [CrossRef] [PubMed]

76. Šimůnek, J.; Šejna, M.; Saito, H.; Sakai, M.; van Genuchten, M.T. The HYDRUS-1D Software Package for Simulating the Movement of Water, Heat, and Multiple Solutes in Variably Saturated Media; Version 4.16; HYDRUS Software Series 3; Department of Environmental Sciences; University of California Riverside: Riverside, CA, USA, 2013.

77. Van Genuchten, M.T. A closed form equation for predicting the hydraulic conductivity of unsaturated soils. Soil Sci. Soc. Am. J. 1980, 44, 892-898. [CrossRef]

78. Schaap, M.G.; Leij, F.J.; van Genuchten, M.T. Rosetta: A computer program for estimating soil hydraulic parameters with hierarchical pedotransfer functions. J. Hydrol. 2001, 251, 163-176. [CrossRef]

79. Building Code Act. Ontario Regulation 332/12. Building Code. Section 8.7.3. 1992. Available online: https://www.ontario.ca/ laws/regulation/120332 (accessed on 10 October 2018).

80. Sudicky, E.A.; Frind, E.O. Contaminant transport in fractured porous media: Analytical solutions for a system of parallel fractures. Water Resour. Res. 1982, 18, 1634-1642. [CrossRef]

81. Tang, D.H.; Frind, E.O.; Sudicky, E.A. Contaminant transport in fractured porous media: Analytical solution for a single fracture. Water Resour. Res. 1981, 17, 555-564. [CrossRef]

82. Marshal, R.; Levison, J.; McBean, E.; Parker, B. Wastewater impacts on groundwater at a fractured sedimentary bedrock site in Ontario, Canada: Implications for First Nations' source-water protection. Hydrog. J. 2019, 27, 2739-2753. [CrossRef]

83. Perrin, J.; Parker, B.L.; Cherry, J.A. Assessing the flow regime in a contaminated fractured and karst dolostone aquifer supplying municipal water. J. Hydrol. 2011, 400, 396-410. [CrossRef]

84. Manger, G.E. Porosity and Bulk Density of Sedimentary Rocks; United States Government Printing Office: Washington, DC, USA, 1963.

85. Lin, L.; Lin, H.; Xu, Y. Characterization of fracture network and groundwater preferential flow path in the Table Mountain Group (TMG) sandstones, South Africa. Water SA 2014, 40, 263-272. [CrossRef]

86. Ministry of the Environment, Conservation and Parks (MECP). Water Supply Wells: Requirements and Best Practices. 2018. Available online: https://www.ontario.ca/document/water-supply-wells-requirements-and-best-practices/siting-well (accessed on 16 October 2021).

87. Allen, A.S.; Borchardt, M.A.; Kieke, B.A., Jr.; Dunfield, K.E.; Parker, B.L. Virus occurrence in private and public wells in a fractured dolostone aquifer in Canada. Hydrogeol. J. 2017, 25, 1117-1136. [CrossRef] 
88. Saugeen, Grey Sauble, Northern Bruce Peninsula Source Protection Region. Chapter 6: Source Protection Plan Policies. 2016. Available online: http://home.waterprotection.ca/wp-content/uploads/2018/06/SPP_Ch6_Policy_for_Threats_Approved.pdf (accessed on 16 October 2021).

89. Hamilton, S.M.; Brunton, F.R.; Priebe, E.H. Regional-scale mapping of buried, surface-connected, karst groundwater systems using dissolved $\mathrm{CO}_{2}-\mathrm{O}_{2}$ in groundwater. In Proceedings of the GeoOttawa 2017: The 70th Canadian Geotechnical Conference and the 12th Joint CGS/IAH-CNC Groundwater Conference, Ottawa, ON, Canada, 1-4 October 2017. 